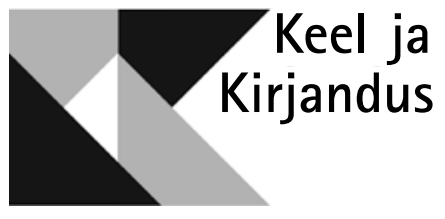

\title{
PSÜHHOANALÜÜTILINE UNT
}

\author{
MAARJA VAINO
}

$\mathrm{R}$ aske on anda ühemõttelist vastust küsimusele: missugune kirjanik oli Mati Unt? Tegu on mitmepalgelise ja natuke „kinnipüüdmatu” loojaUnatuuriga. Aga kui ometi proovida sõnastada vastuseid, siis üks vastus võiks olla: psühhoanalüütiline kirjanik.

\section{Mati Unt ja psühhoanalüüs}

Mati Undi huvi psühholoogia ja psühhiaatria vastu sai sügavama sisu ülikooli ajal. 1960. aastate teatriuuenduse käigus muutus Undi huvi „möödumatuks Jungi-hulluseks" (Unt 2004: 56).

Anti Liiv meenutab: „Mati oli ülimalt huvitatud nii psühholoogiast kui ka psühhiaatriast, eriti psühhoanalüütilise suunaga psühhiaatriast. Luges sel teemal palju ja tegi oma ilusa, veidi naiseliku käekirjaga loetust huvitavaid väljakirjutisi. Oli nauding neid kladedesse kogutud märkmeid lugeda" (Liiv 2008: 98). Kahjuks on kladed praegu teadmata kohas. Kirjandusmuuseumisse loovutatud materjalide hulgas neid arvatavasti ei ole (arhiiviseadus piirab küll ligipääsu kogu ainesele).

On ilmne, et loetu avaldas Undile mõju nii isiklikus (enese analüüsimine) kui ka loomingulises plaanis. Undi teostes esineb nii otseviiteid psühhiaatriale (nt korduvad viited Korsakovi või Kandinsky sündroomile jm terminoloogiat) kui ka varjatumaid tasandeid, millest võib välja lugeda psühhoanalüütilisi kujundeid. 
Järgnevalt püüan kaardistada Undi asjakohast lugemust ja seda, kuidas ilmutab psühhoanalüütiline substants end kirjaniku tekstides.

Kuna Unt lähenes kogu temaatikale loominguliselt, kasutan „psühhoanalüüsi” kui katusmõistet, mis hõlmab nii psühholoogiat, psühhiaatriat kui ka psühhopatoloogiat, vahel ka neuroloogiat. Samuti kasutan ühesuguses tähenduses vaheldumisi mõisteid „,alateadvus”, „mitteteadvus” ja „teadvustamatus”, et vältida liigset sõnakordust.

\section{Raamatukogu}

Taustaks olgu väike ülevaade Undi raamatukogust. 2014. aastal koliti suurem osa Mati Undile kuulunud raamatukogust tema ja Lii Undi Koidula tänava korterist Eesti Kirjandusmuuseumisse Tartus. Märkimisväärne hulk üle tuhande nimetusega raamatukogust puudutab nii eesti- kui ka võõrkeelset psühholoogiaalast kirjandust. Raske on tagantjärele öelda, millal Unt ühe või teise - eriti võõrkeelse - teose endale hankis. Samuti on keeruline öelda, millal on ta nendesse raamatutesse teinud allakriipsutusi või märkmeid. Tõenäoliselt võiks tuvastada seoseid lavastustega, mille kallal Unt töötas. Kõige suurejoonelisemalt elas Unt oma psühhoanalüüsialaseid teadmisi välja erinevates lavatükkides (etenduste kujundikeeles). Samuti oma näidendites.

Olgu siinkohal esitatud väike loetelu (sugugi mitte ammendav) Undi raamatutest. Undi tegelik lugemus oli mõistagi avaram kui siin esitatud valik. Nõukogude ajal saatis talle temaatilisi teoseid näiteks Mardi Valgemäe, ${ }^{1}$ samuti olid raamatukogus kättesaadavad venekeelsed psühhoanalüüsi käsitlevad teosed, üht-teist liikus käest kätte jne. Võimalik, et mingi osa raamatutest, mida Unt elu jooksul oma riiulitel hoidis, pole üldse kirjandusmuuseumisse jõudnud. Ent siiski annab järgnev nimekiri kätte kirjaniku huvide suuna ja kinnitab, et Undi huvi psühhoanalüütilise kirjanduse vastu säilis elu lõpuni.

Niisiis, raamatud enam-vähem selles järjekorras, nagu nad riiulil olid:

Alfred Adler „Inimesetundmine” (1995); C. G. Jung „Mälestused, unenäod, mõtted” (2004); C. G. Jung „Inimene ja tema sümbolid” (2005); Endel Tulving „Mälu” (2002); Fritz Riemann „Hirmu põhivormid” (1995) ja „Võime armastada” (1998); „Kliiniline farmakoloogia” (1988); „Kliiniline psühhofarmakoloogia” (1981); „Narkoloogia” (1982); Jüri Saarma „Kohtupsühhiaatria” (1972), „Kliiniline psühhiaatria” (1980) ja „Depressioon” (1995); „Neuroloogia taskuraamat” (1997); Veikko Tähkä „Psühhoteraapia alused” (1999); Johan Collberg „Dünaamiline psühhiaatria” (1994); Sigmund Freud „Argielu psühhopatoloogia” (1991); Thomas A. Ban „Depressiivsete häirete diagnostika koondsüsteem” (1992); Lembit Mehilane „Psühhofarmakoteraapia õppematerjalid” (2000) ja „Psühhopatoloogia õppematerjalid” (2000); John Preston „Kuidas jagu saada depressioonist” (1999); „Psüühika- ja käitumishäirete klassifikatsioon RHK-10. Kliinilised kirjeldused ja diagnostilised juhised" (1995); Sue Preton „Milleks muretseda” (1999); Aleksander Pulver „Toimetulek iseendaga” (1991); Alice Miller „Das Drama des begabten Kindes und die Suche nach dem wahren Selbst” (1979); Karen Нorney „Невротическая дичность нашего времени. Самоанализ” (1993); Henrik M. Ruitenbeek „Parantavat ryhmät” (1975); Eino Kaila „Persoonallisuus” (1982); Bruno Bettelheim „The informed

\footnotetext{
${ }^{1}$ Joel Sanga suuline teade 2. II 2016.
} 
Heart” (1991); „The ethics of psychoanalysis. The seminar of Jacques Lacan” (1997); Auli Kaartinen „Sadomasokismi: teemoja vallasta, kulttuurista ja seksuaalisuudesta" (1990). Jne.

Mida sellest loetelust järeldada? On ilmne, et Unti huvitas psühholoogia üsna avaralt - alates n-ö eneseabiõpikutest kuni ülikooli õppematerjalideni välja. Ei ole selge, kui paljusid nendest teostest ta tõepoolest läbi töötas ja kui palju oli põgusat sirvimist, mille käigus siin-seal silma torganud huvitavad mõtted Undi fantaasia tööle panid. Ehk nagu kirjutab Vaino Vahing: „Unt haarab neid KAEMUSI ja teadmusi nii endast kui ka ajalehtedest, monograafiatest, eessõnadest ja lõppsõnadest kuni entsüklopeediateni välja" (Vahing 2008: 299).

Siinses artiklis ei ole võimalik keskenduda kõikidele teemaga seotud aspektidele, sest materjal on tõepoolest rikkalik. Näiteks jäävad kõrvale unenägudega ja unenäolisusega seotud märksõnad, samuti märksõnad, nagu iha ja seksuaalsus.

Ennekõike võtan vaatluse alla Undi üsna silmatorkava vahekorra Carl Gustav Jungi teooriatega.

\section{G. Jung ja Bernarda Alba maja}

Raamatukogu nimekirja silmitsedes on näha, et Undil oli olemas suurem osa eesti keeles ilmunud Carl Gustav Jungi teoseid. Aga see on juba n-ö hilisem kihistus. Muidugi ei ole juhuslik, et Unt on ka ise tõlkinud ühe Jungi raamatu, selleks on „Tänapäeva müüt. Asjadest, mida nähakse taevas” (1995). Teoses on mitmeid tõlkija märkusi, mis reedavad laiemat ja varasemat lugemust kui see, millele osutab arhiivi jõudnud raamatukogu. Minu jaoks oli isegi üllatav, et Jungi võõrkeelseid teoseid raamatukogus rohkem ei leidunud, sest just Jungi ideed paistavad Undi loomingus kõige enam silma. Jung on üks viidatumaid autoreid ka tema „Theatrum mundis”, samuti argimütoloogiates. Vahing meenutab: „...lugesime neil aastail [1970. aastate alguses $-M$. V.] palju Freudi, Jungi, Ericksoni, Unt eriti Jungi" (Vahing 2005: 244).

Üks tähelepanuväärsemaid näiteid psühhoanalüütiliste ideede rakendamisest on Federico García Lorca „Bernarda Alba maja” lavastus (1982), mille Unt on üles ehitanud Jungi anima kujule ning ema arhetüüpidele.

Meenutuseks. Näidendi tegevus toimub majas, kus elab ema koos viie tütre ja teenijatega. Näidend algab Bernarda mehe matustega ning keskendub seejärel ema nõudmisele, et tütred järgiksid kaheksa-aastast leinaperioodi. Ema keelab neil suhtluse (eriti noormeestega) väljaspool maja ning hoiab tütreid oma meelevalla all. Näidend lõpeb ühe tütre enesetapuga. 1936. aastal ilmunud Lorca viimast näidendit peetakse süngeks ja ühiskonnakriitiliseks teoseks, mis keskendub ainult naistele ja kust meeskarakterid on meelega välja jäetud.

Undi arhiivis on kaustik, mis sisaldab „Bernarda Alba maja” lavastusega seotud märkusi ja väljakirjutusi. Oma kaustikus on Unt jaganud Bernarda Alba tütred tüüpideks, mis peegeldavad Jungi käsitust erinevatest emakompleksi all kannatavatest tütardest. Viitest selgub, et lavastaja on seejuures

${ }^{2}$ Anima on mehe alateadvuses esinev naiselik ja animus naise alateadvuses ilmnev mehelik personifikatsioon (Jung 1995: 216). 
kasutanud Jungi „Kogutud teoste” peatükki „Die psychologishe Aspekte des Mutterarchetypus".

Olgu Undi märkused siinkohal ära toodud tegelaskujude kaupa.

Martirio ja Adela: Erose ülearenemine (2013. aasta eestikeelses C. G. Jungi teoses „Neli arhetüüpi” on sama tüüp tõlgitud kui „Ülemäärane eeros” - Jung 2013: 36). Unt on kaustikusse kahe tegelase kirjeldamiseks märkinud: „Alateadlik intsestlik suhe isaga. Armukadedus ema vastu, soov teda üle trumbata. Tihti purustavad ettevõtted. Armastavad romantilisi ja sensatsioonilisi episoode, on huvitatud abielumeestest. Nad on pimedad selle suhtes, mida nad teevad [---]. Passiivse Erosega meestele on ta hea konks anima-projektsioonidele."

Angustias: identsus emaga. „Tütre naiseliku initsiatiivi paralüüs. Ema on talle supernaine. Ta ripub ema küljes, isetult, samal ajal püüdes ema türanniseerida, lojaalsuse maski all. Shadow-existence."

Magdalena: vastuhakk emale. „Ükskõik mida, mitte ainult ema! Ühelt poolt lummus, mis iial ei leia identifikatsioonipunkti, teisalt Erose intensiivistumine, mis ammendab ennast armukadedas mässus."

Undi kommentaarid vastavad täpselt Jungi kirjeldatud tunnustele, mis toovad esile negatiivsed suhted ema ja tütre vahel. Sealsamas on Unt teinud väljakirjutusi mitmesuguste emaarhetüüpide esinemise kohta Jungil (näiteks meri, vesi, allilm, kuu, põld, aed, kalju, koobas, mets, maa, kaev, allikas, draakon, nõid, pikk kala, madu, haud, sarkofaag, sügav vesi, surm, kummitused). Ta lõpetab „Bernarda Alba maja” lavastuse tarbeks tehtud märkused lausega: „Draakon, kes sööb oma lapsi.”

Tähelepanuväärne on see, et oma lavastuses on Unt ema Bernardat mängima pannud meesnäitleja (Ago Roo). Nii markeerib Unt ühelt poolt seda, et võimukus on seotud mehelikkusega, st võimukat naist peetakse igal juhul mehelikuks; ning teisalt seda, et ka meesteta majas „kontrollib” sealsete naiste elu nn meeste maailmas kehtiv ühiskonnakorraldus (see oli Gárcia Lorca ühiskonnakriitiline sõnum). Kuna aga Unt tõlgendab Gárcia Lorca näidendit Jungi arhetüüpide kaudu, saab „meesema” psühhoanalüütilise lisaaktsendi. Isa/ mehe/kihlatu puudumine ja asendumine emaga viitab selles tõlgenduses ennekõike tütarde probleemidele kontakteeruda oma sisimas oleva animus'ega (omaenda meheliku personifikatsiooniga). Türanlik ema kehastab sellisel juhul hoopis tütarde sisimaid psühholoogilisi takistusi, mis nood on emale projitseerinud ja mille sügavam taust viitab võimetusele tulla toime meessooga.

Näidend pakub suurepärast materjali Jungi teooriate rakendamiseks õige mitme rakursi alt. Lisaks sellele, et tütreid võib liigitada emakompleksi arhetüüpide järgi, on ka maja ise psühhoanalüütiliselt tugeva laenguga märksõna.

Maja on psühhoanalüüsis samastatav isiksusega ning vahel ka naisega. Unt on selle seose loonud näiteks luuletuses „Samoraskrõtije”:

Avan ennast, avan nagu ust

Mille taga peitub ainus keeldud tuba

Toa sisemus on must

Tuppa astuda mul puudub ema luba

Sinna astub hoopis võ̃ras mees

Teeb seal kõike mida tahab 


\section{Nothing is real}

Strawberry fields forever (Vahing 2004: 89).

Samuti võrdleb Unt maja ja inimest palas „Igavesti surev talu”, kus jutustaja läheb oma kaaslasega mahajäetud majja ning kaaslane hakkab vaatama, kas on vanu asju, mida annaks sealt päästa või kaasa võtta. Peategelases tekitab see tõrget ja ta tunneb: „Mõistsin äkki, et viibime laiba kõhus, surnu sisemuses. [---] Kas hingas keegi? Kõik majad ju hingavad, ka elusad majad. Teadsin seda lapsest saati" (Unt 1976: 19).

Lavastuse „Vaimude tund Kadrioru lossis” kohta ütles Unt: „See kujutab endast mõtisklust ruumi üle ja mitte ainult lossi, vaid ka muu ruumi üle - pööningu, nurkade, sahtlite ja alateadvuse üle" (Vaimude tund 2000).

„Bernarda Alba maja” lavastuses on Unt (ja kunstnik) maja kujutanud vanglana, lava piiravad kivimüürid ja okastraat. Mõistagi illustreerib selline kujundus kogu tegevuse õhustikku, viidates Bernarda (see on tema maja) ahistavale olemusele. Kuid kui tõlgendada maja inimesena, võime lavakujunduses (ja etenduses) näha ka otsekui kellegi sisemuses toimuvat erinevate tungide ja komplekside võitlust. Kogu majas toimuv etendab sellisel juhul teadvustamatuses aset leidvaid tunglemisi ja änge.

Unt on „Bernarda Alba maja” lavastuse niisiis varjamatult üles ehitanud Jungilt saadud inspiratsioonile ja võimalik, et andnud sellega näidendi retseptsioonile isikupärase nüansi laiemaltki.

Omamoodi kontrollib Unt selles näidendis ka Jungi ennast ja seda, kas arhetüübid $^{3}$ hakkavad tööle. Eriti näitlejate, aga muidugi ka vaatajate peal. Mängu (teatri) ja elu vaheliste piiride hajutamine oli osa Spiel'ist, mis Unti, Vahingut ja teisi köitis.

„Minu teatriglossaariumis” kirjutab Unt arhetüüpide käivitumisest peatükis „Unenäod”: „Carl Gustav Jungi sümboolika hakkas äkki ilmnema peategelaste unenägudes: vesi, tuli, ring jne. Jaan Tooming nägi unes, et Hermaküla sunnib teda, väikest poissi, jooksma mööda treppi alla ja hüppama basseini (režissöör sunnib näitlejat süvenema oma alateadvusse). Mare Puusepp nägi unes, et pimedas toas läheb uks lahti ja valgus tungib sisse (inimene ärkab puhtale religioossele tunnetusele). Jungi järgi pole kunstnik muud kui kollektiivse alateadvuse tööriist, järelikult väljaspool head ja kurja” (Unt 2009: 99-100).

„Bernarda Alba majas” sai Unt seega teise autori loomingu kaudu lavastada tegelikult Jungi ja tuua vaatajate ette neid ideid ja avastusi, mida ta pikema aja jooksul enesesse oli kogunud ja mis otsisid väljapääsu kunstivormis.

${ }^{3}$ Arhetüübid, nagu kirjutab Jung, „on alateadlikud eelvormid, mis tunduvad olevat psüühika päritud struktuuri osad ja mis võivad igal ajal ja igas kohas spontaanselt ilmneda. [---] [A]rhetüüpi ei määra tema sisu, vaid ainult vorm ja sedagi vaid väga piiratud määral. Algpilt (vt.) on sisuliselt määratletav ainult siis, kui ta saab teadlikuks ning täidetakse teadvusliku kogemusmaterjaliga" (Jung 1995: 218-219). 


\section{Dionysose saabumine}

Jungilik arhetüüpide ideestik mängib olulist rolli ka Mati Undi enda näidendis „Vend Antigone, ema Oidipus” (ilmunud 2006, valminud 2001-2003). Unt on asetanud näidendi keskmesse tuntud müüdi Oidipusest, kuid seob selle laiemalt Teeba linna ajaloo ja teiste müütidega. Nagu ta ise järelsõnas märgib: „Selle näidendi aluseks on võetud vana-kreeka tragöödiad: põhiliselt Sophoklese „Kuningas Oidipus” ja „Antigone” ning Euripidese „Bakhandid” ja „Foiniiklannad”. Kuid on ka reministsentse näidenditele, nagu Sophoklese „Oidipus Kolonoses”, Aischylose „Seitse Teeba vastu” ja Aristophanese „Konnad”. [---] Loo korrastus jälgib nn. Teeba tsüklit” (Unt 2006: 95).

Näidendi kogu sisu ümber jutustada läheks pikale ja keeruliseks. Oluline on, et autor tõlgendab siin vanakreeka müüte. Psühhoanalüütilisest vaatepunktist on müüdid levinuimad kollektiivse alateadvuse ja arhetüüpide kujutajad: sümbolid, mis nõuavad psühholoogilist seletust (Jung 1995: 37, 71). Müüdi lavastamine tähendab seega inimpsüühikale omaste, ent irratsionaalsete või lihtsa seletuseta käitumismustrite esiletoomist ja tõlgendamist alateadvuslike aspektide kaudu.

Vahelepõikena. Kõnesolevas näidendis on Unt ammutanud inspiratsiooni ka Jacques Lacani ideedest (kes toetus valdavalt Freudile). Undi raamatukogus olevast Lacani seminarist (,The ethics of psychoanalysis. The seminar of Jacques Lacan”) on osa („The articulations of the play”; „Antigone between two deaths") pühendatud Antigone kuju analüüsile (küll ennekõike tõlkespetsiifilisest aspektist). Unti on selles artiklis huvitanud aines, mis näitab Antigonet ebainimliku, toore ja metsikuna (Lacan 1997: 263), samuti ettemääratud onnetuste ahel (Lacan 1997: 264), Antigone teispoolne (jumalik, divine) olek ning sellega seotud piirsituatsioon. Kuid hoolimata Lacanist on Undi näidendis kandev roll Jungi ideedel.

Näidend algab võõra jumala Dionysose saabumisega linna. Hakatakse praktiseerima Dionysose kultust, linna naised kogunevad orgiale ja mehed hakkavad jooma. Seetõttu otsustab Teeba kuningas Pentheus Dionysose vahistada ja käivitab sellega katastroofiahela.

Näidendis öeldakse Dionysose kohta: „Ta uusi suundi esindab: / teatrit, hullust, hämarseisundeid, / meesnaist, naismeest, / ja jumalinimest ja inimjumalat / ja üldse igasugu kahemõttelisust ja ekstaasi" (Unt 2006: 10).

Võrdleme Undi teksti Jungi kirjeldusega teosest „Inimene ja tema sümbolid”: „Dionüüsoslik religioon sisaldas ohjeldamatuid riitusi, mis nõudsid pühendatavalt oma loomalikule loomusele alistumist.... Siirderiituse läbiviimisel kasutati abivahendina veini, mis pidi esile kutsuma teadvuse sümboolse hägunemise. Seda oli vaja noviitsi juhatamiseks looduse hoolikalt valvatud saladuste maailma" (Jung 2005a: 148).

Dionysose saabumisega on Unt paigutanud siirderiituse oma loo algusesse. Kõike järgnevat saab seeläbi tõlgendada kui psüühilist protsessi, mille niisugune riitus on käivitanud ja mis viib lugeja/vaataja kummalisse „hämarseisundis maailma”. Lisaks ajaloolise aja hämarusse, sest nagu Unt näidendiga seoses sedastab: „miks mitte läheneda veidi Euroopa kultuuri alghetkedele?” (Unt 2006: 96).

Dionysos algatab katastroofide ahela, mida võime nimetada ka transformatsiooniprotsessiks. Näidendis läbivad tegelased erinevaid psüühilisi staa- 
diume ning kehastavad mitmesuguseid arhetüüpe ja komplekse. Siinkohal oleks keeruline ja aeganõudev kirjeldada näidendi kõiki seoseid nii Jungi seisukohtade kui ka kreeka müütidega (ning Jungi arusaamu kreeka müütidest). Seetõttu markeerin vaid mõned olulisemad punktid.

On tähelepanuväärne, et tegelased räägivad aeg-ajalt mõistetamatus keeles: „[t]ema tekstid on arusaamatud, nagu ikka võõra jumala omad” (Unt 2006: 5). „Võõras jumal” ja arusaamatu keel viitavad teadvuse varjupoolele. Anonüümne „mass” (unenägudes) esindab Jungi tõlgenduses samuti teadvustamatuse substantsi ning näidendis on anonüümsel kooril ja bakhantidel sama roll. „Hämarseisund” on kohal ja asub sündmustikku juhtima.

Oluline kuju selles hämaras protsessis on pime Teiresias, keda jumalad muudavad kord meheks, kord naiseks. Tema kaudu on Unt sisse toonud anima ja animus'e ning seeläbi omakorda hermafrodiidi temaatika (see ilmneb ka pealkirjas). Hermafrodiit on Jungi töödes oluline sümbol: ta esindab kõige tugevamate ja erinevamate vastaspoolte ühendust. Teiste sõnadega: hermafrodiit sümboliseerib terviklikku ISE-t (Selbst), mis on endasse hõlmanud nii oma negatiivse varju ${ }^{4}$ kui ka leidnud tasakaalu anima ning animus'e vahel (Jung 1981: 292-294). Pime Teiresias on seega näidendi kese. Pime osutub ainukeseks nägijaks. Kohe näidendi alguses ütleb ta: „Maailma välist pilti ma ei näe, / see-eest ma näen ta olemust” (Unt 2006: 9).

Mis eriti oluline, Teiresias on ennustaja ning küsib pidevalt: „Mis tegelikult toimub?" Ta viitab vajadusele sukelduda alateadvusesse ja integreerida sealolev teadvusesse. Pime ennustaja on otsekui võrdväärne pimeda juhusega - ent juhuseid psühhoanalüüs ei tunnista. Seetõttu on ennustaja/alateadvus pigem saatuse metafoor. Osalt on pimedal Teiresiasel sama roll, mida Jung näeb olevat unenägudel ja fantaasial: ta vahendab sõnumeid mitteteadvusest ja ennustab muutusi (transformatsiooni, individuatsiooni). Undi näidendis toimuv sobitub hästi Jungi kirjeldusega alateadvuse esiletungist ning kollektiivse ja individualistliku alateadvuse konfliktist: „Sellepärast pean ma tasakaalu kaotust otstarbekaks - mittefunktsioneeriva teadvuse asemel hakkab alateadvus automaatselt ja instinktiivselt tegutsema, eesmärgiga saavutada uus tasakaal, mis saavutatakse eeldusel, et teadvus on võimeline alateadvuse poolt toodetud ainest assimileerima, s.t. sellest aru saama ja seda töötlema. Kui alateadvus teadvuse suhtes peale jääb, tekib psühhootiline seisund. Kui ta ei suuda täielikult teadvusse jõuda ja end mõistetavaks teha, tekib igasugust edasist arengut halvav konflikt. [---] Teadliku suhtumise kokkuvarisemine pole tühiasi. See on alati peaaegu nagu maailma lõpp, tagasipöördumine algse kaose juurde" (Jung 2005b: 56-57). Undi näidendis juhtubki see, mille eest Jung hoiatab. Ei suuda Oidipus ega mitmed teised tegelased Dionysose vallandatud kaost korrastada ning loo lõpus näeme Teatajat ütlemas: „Kuid töötab edasi me traagiline põrgumasin. / Ei ole moiradel veel küllalt saand. / Hädad uued su peale kohe kuhjuvad. // KREON: „Oimoi. Mis juhtuda veel pärast seda võis? Aiai, aiai. // TEATAJA: Vaata ise. Kohe juhtub” (Unt 2006: 81-82).

${ }^{4}$ Vari on Jungi kohaselt isiksuse alam osa, kõikide nende isiklike ja kollektiivsete psüühiliste elementide summa, mis ei sobi teadlikult valitud eluhoiakuga ja mida ei saa realiseerida. Varju teadvustamine on analüüsi algetapi ülesanne. Varju tähelepanuta jätmine või väljatõrjumine, aga ka enda samastamine Varjuga võivad viia ohtlike vastuoludeni (Jung 1995: 227-228). 
Ja päris lõpus ütleb väsinud Dionysos: „Päev oli väsitav, / ja ajalugu ka, / ja kogu legendide sudu. / Kui mõtlen ette veel, / et pärast tuleb jälle sõda, / on epigoonne sõda nimeks sel, / sest lähisugulased omavahel tülli lähevad, / ja Teeba lõplikult kaob aastasadadeks maailma kaardilt, / et saada pisilinnaks tänapäeval, / mis turistegi ei enam huvita, / kuid kus siiski lähimägedes / on kuuldavasti rajatamas monumenti, / mil nimeks „Oidipuse pojad”, / siis - õed ja vennad, emad, isad, pojad - / see on kui unenägu, mida / ma täna rohkem vaadata ei soovi" (Unt 2006: 82-83). Näidend lõpeb identiteedivahetusega: Ismenest saab Ariadne. Mingisugune transformatsiooniprotsess on teoks saanud. On lootust, et Ariadne lõng viib lõpuks kaosest välja.

„Bernarda Alba majaga” võrreldes ei huvitanud Unti oma näidendis niivõrd Jungi „lavastamine”. Pigem võimaldavad psühhoanalüütilised ideed siin väljendada sügavamaid, tõsisemaid mõtteid, mis kirjanikul oma viimast näidendit kirjutades peas mõlkusid.

Milliseid sõnumeid püüdis Unt edastada sellega, et tõi ajaloohämarusest välja müüdid, Euroopa kollektiivse alateadvuse? Ilmselgelt tahab ta Dionysose suu läbi öelda, et on väsinud - aga millest? Euroopast ja ajaloost? Kultuuritsüklite paratamatust kordumisest? Inimese aheldatusest iseendasse? Või ajaloo unustamisest („turistegi ei enam huvita”)? Segastest aegadest ja päevapoliitikast? Massikultuurist ja labasusest? Või markeerib ta sellega teatavat Undi-väsimust, mis oli tema ümbruskonnas mõnevõrra maad võtnud? Ja sellest tulenevalt väsimust ka iseenda või olemise suhtes üleüldisemalt? Midagi sellest on kirjutatud näidendisse „Vend Antigone, ema Oidipus”.

\section{(Ema) Oidipus}

Mõistagi torkab Undi näidendi puhul silma ka märksõna „Oidipus”. Algselt Freudi sõnastatud Oidipuse kompleks sai oma nime müüdi järgi Teeba kuningast Oidipusest, kes teadmatusest tappis oma isa ja abiellus oma emaga. Freud tõi mõiste kasutusele 1897. aastal ühes kirjavahetuses, kus ta pärast oma isa surma tegeles eneseanalüüsiga (Rycroft 1995: 118-119). Teadvustamata plaanis väljendub Oidipuse kompleks soovina tappa samasooline vanem ja abielluda vastassoost vanemaga. Kaasaegse Oidipuse kompleksi tõlgenduse eelkäijaks peetakse Jungi, kes tõi paralleelselt mängu Elektra kompleksi. See on Oidipuse kompleksi n-ö vaste tüdrukutel ning rõhutab emakomplekside tähtsust. Omal ajal ei leidnud see kontseptsioon toetust ja hüljati teiste psühhoanalüütikute poolt (Borovećki-Jakovljev, Matačić 2005: 353). Jungi käsitluse detailidel peatumata võib Undi näidendi pealkirjas (ema Oidipus) ja mitmes muus elemendis näha idee mõjutusi - ning mõistagi võib siin leida ka vihjelise paralleelsuse Bernarda Alba majaga.

Oidipuse kompleks ei ilmu välja ainult müütilises näidendis, vaid esineb üsna silmatorkavalt ka proosapalades. Sealjuures on oluline, et Undi loomingus kerkib Oidipuse kompleks esile vaid poolikuna, n-ö isatapumotiivina. Iha abielluda emaga ei ole tema tegelaste puhul märgata. Noore ja vanema mehe konflikte aga küll.

Mõned näited. 1974. aastal ilmunud „Mattiases ja Kristiinas” (võime Mattiases aimata ka Matit) töötab Mattias fotolaboris ja tema ülemuseks on üks vanem mees. „Mattias oli ta vastu hea olnud ja tahtis nii väga, et hall, lastetu 
vanamees teda, isatut (isa elas maal) armastaks, aga vanamees ei teinud seda, läks ära, ja Mattias vaatas tema selga äkki vihkava pilguga, enda jaoks liigagi vihkavalt" (Unt 2009: 174).

Mõne aja pärast põgenevad Kristiina ja Mattias metsa, mis meenutab Mattiasele isakodu. „Ent Mattiasele tundus, et ta on jõudnud maale, tagasi isakoju. [---] Üks talu, üks kindlus seisis metsa ääres. Keskel televisiooniantenniga elumaja, mida kolmest küljest piirasid laut, ait ja saun. Maja taga oli viljapuuaed, mida ümbritses tara. Kui Mattias ja Kristiina õuel seisma jäid, kuulsid nad ainult lehma mäletsemist laudas, aeg-ajalt tema puristamist ja ähkimist. Muru kirendas pimedaski võililledest. Lauda seina ääres pingil kuivas lüpsik, keset õue oli kassi piimataldrik. Mattias tundis, et ta on jõudnud (seekord kindlasti) koju, koos pruudiga" (Unt 2009: 200, 204).

Seejärel aga sündmustiku tonaalsus muutub: tegemist ei ole isakoduga, Mattias üritab majja tungida ning järgneb kaklus talus (vale-isakodus) elava vanema mehega.

„Nad seisid nüüd teineteise vastas. Mattias ei seletanud mehe nägu. [---] ...tormas ta ühe hüppega mehe juurde, kes ei jõudnud püssi uuesti tõsta, haaras püssist kahe käega kinni, ühega torust, teisega kabast. Nad rähklesid tükk aega sõnatult, tummalt, ägades ja ähkides. Mattias haistis mehe higilõhna. Korraks puutus ta põsk vastu mehe karvast põske ja talle tundus, et see on ta isa. Nagu oleks ta vaimu näinud, haaras teda pime hirm, ta oleks jooksu pistnud, kui ta käed poleks püssist kinni hoidnud. [---] ... Mattias astus püssist lahti laskmata sammu tagasi ja lõi mehele terava kinganinaga tugevasti kõhtu. Mees laskis püssist lahti, astus kaks sammu tagasi, vajus kummargile ja puhkes kätega kõhust hoides peenikese häälega nutma, täpselt nagu isa siis, kui hobune teda kabjaga lõi. (Mattias mäletas, et isa toibus varsti, haaras rihma ja hakkas hobust vastu silmi peksma, metsik ja võõras, kuutõbine.) Püss oli nüüd Mattiase käes, äsjasest haardest soe, minevikuhaardest libe, raske, nüüd oli Mattias selle küla valitseja, isand, ja ta vaatas üksisilmi, südame kloppides enda ees küünitavat eakat, valges aluspesus meest” (Unt 2009: 207).

Isa suhtes tunneb ebameeldivust ka poeg romaanis „Ja kui me surnud pole, siis elame praegugi” (1973): „Ehkki tal polnud oma isale midagi ette heita, ei suutnud ta üle olla moodsast isavõitlusest" (Unt 2009: 250).

„Moodne isavõitlus” on viide isakompleksile, mida nii Freud kui ka Jung käsitlesid osana oma psühhoanalüüsist ning mis Freudi puhul viitab n-ö algmõrvale (raamatus „Tootem ja tabu”): pojad imetlevad ja vihkavad oma isa ühtaegu tema tugevuse ja võimu pärast. Isa tappes ja ära süües saavad nad tema jõu ja võimu endale. Nii et kui Mattias haarab vanamehelt relva ning tunneb end isanda ja küla valitsejana, on see küllaltki freudistlik olukord.

Mulle tundub, et „moodne isavõitlus” oli Undil osalt ka isikliku taustaga. Suhted isaga ei olnud eriti lähedased, samuti vaevas Unti „maapoisi” identiteet, mis seostus samuti isataluga. Demonstratiivne linnaelaniku hoiak võis olla üks osa kirjaniku isiklikust „isavõitlusest”. Maire Jaanus on Undi iroonilise kirjutamisstiiliga seoses märkinud: „See määratlus sobib nende jutustajate kohta, kes ei suuda samastuda isaga ja jäävad seetõttu tegevusetu iroonia positsioonile, hulpides tülpimuses, mängulisuses, mis sisaldab veidi passiivset künismi, hamletlikku ja köitvat" (Jaanus 1990: 55).

Kuid tagasi Undi loomingu juurde. Lähtudes sellest, et Unti huvitasid rohkem Jungi ideed, tuleb arvesse võtta, et Jungil on kõik võitlused kokkuvõttes 
seotud transformatsiooni või individuatsiooniprotsessiga. „Kui isa mõjub kaitsena välismaailmast tulevate ohtude eest ja on seega pojale Persona eeskujuks, siis ema kaitseb ohtude eest, mis pimedusest poja hinge ähvardavad" (Jung 2005b: 100). Ühel hetkel tuleb aga lapsel vanematest eralduda ning see võib olla erakordselt raske ja keeruline protsess. Tihtipeale õnnestub see ainult autoriteedi väljatõrjumise ja sellele negatiivse tähenduse omistamisega (Jung 2005a: 88).

Undi huvi jungiaanliku individuatsiooni vastu süvenes elu jooksul. Kui varasemas proosaloomingus on viited isiku uuestisünnile pigem vihjelised, siis hilisemas näidendis „Graal!” (2001) on Unt toonud Jungi ideed esile konkreetsete märksõnadena.

\section{Individuatsiooniprotsess}

Jungi seisukohalt on individuatsioon isiksuse kõrgeim eesmärk.

„Kasutan väljendit „individuatsioon” märkimaks protsessi, mille käigus inimesest saab psühholoogiliselt in+dividuus, eriline, jagamatu ühik või „tervik". [---] Individuatsioon tähendab saada ainsuslikuks homogeenseks olendiks. Kuna „individuaalsus” tähendab meie kõige sisimat, viimast ja jagamatut ainulaadsust, siis on individuatsioon iseendaks saamine," kirjutab psühhoanalüütik (Jung 1995: 221).

Tuleb tunnistada, et „iseendaks saamine”, „teelolek iseenda juurde” jmt on tänapäeval ülekasutatud väljendid, mis enamasti ei toetu Jungile, vaid evivad pigem naisteajakirja tõlgendust ja aurat. Jung märgib ka ise, et tema ideed individuatsioonist on raske selgitada ning esineb mõistelist segadust: „Märkan ikka ja jälle, et individuatsiooniprotsess aetakse segamini MINA (ego) enesest teadlikuks saamisega ja et MINA aetakse segi ja samastatakse ISEga, mis loomulikult tekitab lootusetut mõistelist segadust. Sel juhul muutuks see paljaks enesekesksuseks ja autoerotismiks" (Jung 1995: 221).

Minu hinnangul võtsid Unt jt Jungi ideid küllaltki tõsiselt. Need ei olnud ainult põnevad kujundid, vaid neis nähti reaalset seost oma eluga. See ilmneb näiteks Undi arutluses Hermaküla üle: „Ei saa lahti tundest, et Evald pani pirrud kahest otsast hõõguma, et teadvus ja alateadvus kiiremini kokku saaks. (Ehmatusega lugesingi seda lauset paar nädalat hiljem ta mõttepäevikuid litereerides.) Mis võis olla selle kaugem eesmärk? Mitte enam teater lõbustusartikli või meelelahutusena, nagu enamik inimesi sellest aru saab. Eesmärgiks pidi olema just mingi suurem läbilöök, midagi täiesti suurt ja lootusetut, täiesti uus olek ilma suhtes, jah, niisiis erakordne individuatsioon. Kuid Jung on hoiatanud, et individuatsioon ei ole kõigile soovitatav ja võib isegi ohtlik olla" (Unt 2004: 247).

Vahing meenutab pingeseisundeid 1960.-1970. aastate vahetusel enda, Undi jt elus ning nendib: „Freud Freudiks, lugemus ja analüütiline haritus on head asjad, aga midagi peab ka endal ja enne Freudi olema. Arvan, et mul ja meil see oli. See, mis oli ja kirjutama sundis, oli hing e s e is und. Ja selline seisund oli mul, oli Undil, Kõivul" (Vahing 2005: 247).

Undi elus toimus sel ajal oluline murrang: teise abielu lahutamine ja uus armusuhe, kolimine teise linna (võõrasse kohta, vastu teadmatusele), töökohavahetus. Kuna Unt reflekteeris pidevalt omaenda elu, siis loomulikult 
kajastub see murrang üsna avameelselt ka tema teostes. Märkame kujundikeelt, mida Unt on kasutanud muudatuse tähistamiseks. „Tühirand” (1972) on juba pealkirja poolest tähenduslik: rand kui piiripealne paik, tühjus kui muudatuse eelseisund.

Unt seostab oma loomingus merd transformatsiooniga: „Kui räägitakse puhtakssaamisest, siis võib see ainult mere ääres juhtuda” (Unt 2008: 156). „Tühirannas” on üks mereepisood psühhoanalüütilisest vaatepunktist lausa sõnumilaadne. Peategelane on üksi mere ääres. „Joonistasin liivale maagilisi vormeleid. Aeg, mida ma viitsin, liikus pikkamööda, aeg voolas ja ma tahtsin ta surnuks lüüa, see aeg ei tulnud enam kunagi tagasi, see aeg tuli maa ja mere pealt ja läks sinna, kust ta tulnud oli. Päike kõrvetas. Ma hakkasin madalas vees liivasesse põhja AUKU kaevama, et ennast üleni ära peita; töötasin mõlema käega, töötasin nagu ekskavaator, higi voolas mu huultele, liiv aga voolas auku tagasi, kuid kõigele vaatamata mu töö edenes ja lõpuks istusin auku ja tõmbasin ennast hästi kössi, nii et ainult pea veest välja jäi. Vaatasin ringi. TÜHIRAND. Ei ühtki konkreetset tunnust. Anonüümne maa. Ükskõik mis riik parasvöötmes. Valge leht, valge rand, valgerand. Ma olen siia tulnud läbi emakakaela" (Unt 2009: 20).

Silmanähtav paralleel tekib looteseisundiga - kössi tõmbunud inimene merevees, pea nagu emakakaelast välja ulatumas. Meenutagem siinkohal, et Jung oli see, kes nihutas Freudi isa/mehekesksuse rohkem ema/naise poole, kus see püsib psühhoanalüüsis tänini. Unt seostab eksistentsialistlikku „maailma kukkumist” just lahkumisega emaüsast: „Poeg võpatas ja niuksatas nagu koer. Ema arvas, et ta kukkus unes. Ta ei teadnud, et kukkumisunenägusid võib interpreteerida kui ebamäärast mälestust, mida alateadvusesse jätab emaihust lahkumine. Kes korra on külma maailma kukkunud, ei sel see enam meelest läe” (Unt 2009: 219). Või: „Siis nuuksatas poeg nagu väike laps. Ema! Ema! Poeg tormas ema juurde, kes vestles daamidega. Ta surus oma põse vastu ema põske. Aga ema ei hoolinud õnnetust pojast, kinkis vaid põgusa suudluse ja jätkas pooleliolevat juttu. Poeg ei saanud emalt mingit abi. Ühest üsast tuled välja, aga sisse lähed hoopis teise. Nii sa siis eksled külmas maailmas ja tagasiteed sul ei ole" (Unt 2009: 273).

Võime aga ka küsida: mis vesi see on, milles peategelane kössitades istub? Ja vastata Jungi sõnadega: „Nagu alkeemikud räägivad oma „kivist, mis pole kivi”, nii pole ka nende „filosoofiline vesi” mitte vesi, vaid elavhõbe, ja mitte tavaline metalliline Hydrargyrum, vaid vaim (oneuma, spiritus). [---] Filosoofiline vesi on klassikaline aine, mis muudab teisi keemilisi elemente ja mis ka ise nende muutuste käigus muutub. Ta on ka religioosse lootuse „lunastav vaim"” (Jung 1995: 43-44).

Teiste sõnadega: vees istujaga on toimumas transformatsioon, uuestisünd, mida sümboliseerib ka hetkeline tagasiminek n-ö looteseisundisse. Liiv jookseb tagurpidi, aeg kerib tagasi, rand ja inimene sellel rannal on „valge leht”.

„Tühiranna" tsitaadis on aga veelgi olulisem see, et peategelane joonistab liivale maagilisi vormeleid, teiste sõnadega: mandalat. Mandala on Jungi üks olulisemaid termineid, mis tähistab kujundlikult individuatsiooniprotsessi. „Tänapäeva müüdi” Jungi-glossaariumisse on mandala märksõna alla kirjutatud: „Jungil keskpunkti, eesmärgi, ISE (psüühilise terviku) sümbol, psüühilise keskendumisprotsessi väljendus, isiksuse uue tsentrumi loomine" (Jung 1995: 224). 
Kõik viitab sellele, et peategelane „kerib tagasi” kuhugi algseisundisse ning sellest algseisundist saab alguse uus protsess, liikumine teisele tasandile - ning lahkuminek naisest saab tõepoolest teoks. (Muide, armukolmnurgad - nii elus kui ka mütoloogias - tähistavad Jungil isiksuse lõhenemist.) Igat sorti konfliktid ja kannatused panevad ego (ISE, Selbst'i) kasvama.

Päris kindlasti kajastab vaadeldud tekstikoht ka autori elus ja psüühikas toimuvat, mille kirjeldamiseks on valitud jungilik mandala-kujund. See markeerib nii isiklikke pingeid kui ka - vähemasti teoreetiliselt - nende lahendust.

Unti huvitasid Jungi müstikasse kalduvad ideed elu lõpuni. Seda kinnitab meile näidend „Graal!”, kus sündmuste käivitajaks on „verepilastuslik tegu”, nagu ka näidendis „Vend Antigone, ema Oidipus”. Kuid „Graalis!” on osaliste seos jungilike arhetüüpidega avalikuks tehtud juba tegelaskujude loetelus: Morgana le Fay, tume anima; Sophia / Maarja Magdalena / Marjatta / Dindrane, hele anima; Elaine, neitsi; Guinevere, femme fatale; Mordred, tume animus, Hitlerstalinlane, Lucifer/Kurat, devil, androgüün. Hilisemas tekstis tunnistatakse Mordred kuningas Arthuri varjuks (Shadow), mis on veel üks otsene Jungi termin.

Unt on nii „Graali!” lõppu paigutatud soovitatavas kirjanduses kui ka „Tänapäeva müüdi" tõlkes viidanud Emma Jungi ${ }^{5}$ ja Marie-Louise von Franzi teosele „Die Graalslegend in psychologischer Sicht”, kus Graal on võrdsustatud ISE-ga (Selbst). Nõnda kujutab näidend erinevate tegelaskujude kaudu jungiaanlikku individuatsiooniprotsessi, mida tekstis tähistavad sellised märksõnad nagu unenäod/nägemused, verepilastus, negatiivne pool, tema oidipuslik rivaal, kollektiivne ihalus; mängu arhetüüp; play, Spiel, game jt, loomulikult ka individuatsioon.

Mängu, Spiel'i, on varem juba mainitud ning iseenesest võiks kogu artikli pühendada selle termini lahtiseletamisele ning Spiel'i ja Undi seostele. Piirdugem siinkohal ühe tähendusliku tekstikohaga „Tühirannas”: „...mäng (Spiel) viib meid tagasi iseenda (Selbst) juurde...." (Unt 2009: 34).

„Graalis!” on individuatsiooniprotsessi algpunkti asetatud Perceval: „Perceval „mängib” nagu laps. Mängu arhetüüp, infantiilsus, mängigu, millega tahes (puulehtede, nukkudega). Tähtis on, et me saaksime aru, et ta mängib” (Unt 2001: 13). Percevali identiteet on alguses „alles embrüonaalne”. Näidendi lõpus on temast saanud aga „Tark Rauk”, alte Weise ehk Carl Gustav Jung (Unt 2001: 98).

„PERCEVAL ( tuld hõorudes): Loobusin elektrist ja keedan ise endale lõkkel süüa. Loobusin veevärgist ja pumpan ise vett. Lihtsad asjad teevad inimese lihtsaks, aga kui raske on olla lihtne. ${ }^{6}$ Graal on minu ego, mis rännakute käigus arenes. Ma vaatan oma südamesse ja näen seal miskit säravat. Olen ainulaadses vaimses seisundis, sest ehkki ma ei esitanud tähtsat küsimust, olen ma nüüd valmis oma südame rinnust rebima ja inimestele teed näitama. Vaat mis teeb üks individuatsioon!" (Unt 2001: 98).

Kuigi undilikus stiilis pisut lõbus-jaburalt nihestatud, on need sõnad oma sisus siiski tõsised. Undi mängud ei olnud sugugi lihtsalt postmodernistlikud

${ }^{5}$ C. G. Jungi abikaasa (1882-1955), kes töötas uurimuse kallal Graalist kolmkümmend aastat. Teos avaldati pärast tema surma C. G. Jungi ja Marie-Louise von Franzi kaasabil.

${ }^{6}$ Episoodis viidatakse ilmselt Jungi sellele eluperioodile, mil ta eraldus maailmast ja võitles oma psüühiliste probleemidega. 
veiderdamised, vaid kandsid sügavamat tähendust. Selle kinnituseks on mainitud tekstikohale järgnev peaaegu manifestilaadne kuulutus: „Elu on mu meelest olnud ikka nagu lill, mis kasvab risoomist. Lille tõeline elu on nähtamatu, see peitub risoomis. See, mis on maa peal, kestab ainult ühe suve. Siis see närbub nagu põgus ilmutus. Kui mõelda elu ja kultuuride lõputut sündimist ja kadumist, siis tundub, et kõik on kaduv, kuid ma olen alati uskunud, et midagi igavest on selle kõige taga. Nähtav osa, lill, on ajalik. Risoom on igavene" (Unt 2001: 99).

\section{Angst, Angst. Mati ise}

Undi noorpõlves alguse saanud huvi psühholoogia ja psühhoanalüüsi vastu saatis teda süvenevalt kogu elu ning mitte lihtsalt ei kajastunud tema loomingus, vaid läbib seda punase lõngana. (Muide, Unt tavatses oma lavastustes ikka kuhugi asetada ka punase lõngakera.)

Mulle tundub, et siin peitub midagi sügavamat kui Vahing, (teatri)uuendus ja üldine ajastutaust. Siin peitub midagi isiklikumat. Undi raamatukogu vaadates torkab silma tema huvi hirme ja depressiooni käsitleva kirjanduse vastu, samuti käitumishäiretega seotud materjal. Mitmes teoses on tehtud allakriipsutusi tekstikohtades, mis tunduvad olevat pigem enesekohase tähendusega ja vähem vajalikud loometööks. Inimese huvialad on alati seotud tema endaga, seetõttu lähtub Undi huvi psühholoogia jm vastu nii või teisiti temast endast, vajadusest seletada ka iseenda probleeme. Muidugi, Unt laiendas selle huvi kõigele - alates müstikast ja lõpetades näitlejatele konkreetsete soovituste andmisega. Kindlasti tulenevad mitmed allakriipsutused tema huvist psüühikanihete kui niisuguste vastu tervikuna. Unti huvitas nihe, hälbimine normaalsusest, sest see oli põnev kunstilis-müstilistel kaalutlustel.

Ning ometi. Kui Unt oli väike, haigestus ta raskesti eluohtlikusse difteeriasse. Ema hirm ainus laps kaotada viis selleni, et edaspidi hoiti Mati tervisel erilise hoolega silma peal ning tõenäoliselt käituti pisut hüpohondriliselt. See võis jätta jälje, mis väljendus enese ja oma tervise ülemäärases jälgimises. Niisugused kahtlused tekivad, kui lugeda näiteks allakriipsutatud tekstikohti ekspressiivse kõnehäire, lapse motoorse koordinatsiooni, üld- ja peenmotoorika avalduste või hüsteeriliste krampide teemal. Ning kahtlused süvenevad, kui loeme näiteks järgnevat äramärgitud teksti Jüri Saarma „Kohtupsühhiaatriast”: „Meeleolu alanemise erivorm on veel hir m u s i s und, mille puhul haige ilma reaalse aluseta tunneb ärevust ning hirmu kas kellegi või millegi ees, kardab, et temaga, tema omastega või kogu maailmaga juhtub mingi katastroof, on hirmul mingi müstilise jõu ees, tunneb seletamatut ja endalegi arusaamatut paanilist hirmu. Sellise hirmu puhul võib haige põgeneda, sihitult hulkuda, aga ka enese tappa, et vabaneda talumatust pingest" (Saarma 1970: 116).

Hirmu ja ärevust käsitlevaid teoseid - ka eneseabiraamatuid - on Undil ootamatult palju. On teada, et elu lõpus moondus see sisemine ärevus haiguseks ja depressiooniks. Kuid see oli lõppmäng. Angst oli olemas juba ammu enne, varakult ja nähtamatu saatjana läbi kogu elu.

Vahing meenutab: „Jääb mulje, nagu oleks Unt esimesena meie ilukirjandusse toonud hirmu mõiste. Võib-olla tõesti, sest ka minu mäletamise järgi 
kordas Unt paarkümmend aastat tagasi üsna sageli ikka Angst ja Angst" (Vahing 1990: 101).

Undi huvi psüühiliste protsesside vastu oli arvatavasti tingitud ka sellest, et seletada iseennast, saada endast, oma hirmudest jagu. Või siis õppida oma probleemidega elama äärmustesse langemata, sest vaatamata kogu huvile individuatsiooni vastu, ei olnud Unt mu meelest valmis võtma sel teemal liiga suuri, hermakülalikke - eluohtlikke - riske. Ta ei tahtnud panna pirdusid kahest otsast korraga põlema. Lähedaste inimeste sõnul oli Unt loomupäraselt üsna terve psüühikaga, kuid väga tundlik inimene. Intelligentne ja tundlik inimene aga tunneb paratamatult kõhedust teadmise ees, et maailmas puudub midagi olulist, mis takistaks kaose sissetungi. See võib olla loominguliselt äärmiselt inspireeriv, kuid isiksusele küllaltki raske koorem kanda.

2005. aasta kevadel oma viimast etendust (Ariel Dorfmani „Surm ja tütarlaps", esietendus 8. IV 2005) tehes ütles Unt, et soovib vormiliste küsimuste asemel tegelda psühholoogiaga. Ta ütles seda ajal, mil elu muutus aina keerulisemaks ja „tema enda arvates üha mõttetumaks” (Liiv 2008: 98).

Nii et siiski. Kogu elu uuritud ja armastatud psühhoanalüüs tasus ennast ikkagi ära. Oli see miski, mis intrigeeris ja hoidis üleval huvi elu vastu, andis sellele lõpuni mingi mõtte või tähenduse.

Percevali kaudu sõnastas Unt ka iseenda tähenduse ette ära. Arhetüübid töötavad alati. Nüüd on Unt ise nagu risoom. See, mis oli maa peal, õitses ja kestis kui põgus ilmutus. Risoom aga on igavene.

\section{Kirjandus}

B or ovećki - Jakovljev, Sanja, Matačić, Stanislav 2005. The Oedipus Complex in the Contemporary Psychoanalysis. - Collegium Antropologicum, nr 29 (1), lk 351-360.

J a a n u s, Maire 1990. Modernism Eestis. Mati Undi proosa. - Vikerkaar, nr 4, lk $55-60$.

Jung, Carl Gustav 1981. The Archetypes and the Collective Unconscious. - C. G. Jung, Collected Works. Vol. 9, Part 1. Princeton, N.J.: Bollingen.

Jung, Carl Gustav 1995. Tänapäeva müüt. Asjadest, mida nähakse taevas. Tlk Mati Unt. Tallinn: Vagabund.

J u n g, Carl Gustav 2005a. Inimene ja tema sümbolid. Tlk Raul Kilgas, Ivar Männamaa, Pille Varmann. Tallinn: Eesti C. G. Jungi Analüütilise Psühholoogia Selts.

Jung, Carl Gustav 2005b. Mina ja alateadvus. Tlk Merike Steinert. Tallinn: Ilo.

J un g, Carl Gustav 2013. Neli arhetüüpi. Ema taassünd, vaim, trikster. Tlk Arne Nielsen. [Tallinn:] Pilgrim.

Lacan, Jacques 1997. The Ethics of Psychoanalysis 1959-1960. The Seminar of Jacques Lacan. New York-London: W. W. Norton \& Company.

Liiv, Anti 2008. Sõnavalaja tühirannal. - Undi-jutud. Mälestusi Mati Undist. [Tartu:] Hermes, lk 96-103.

Rycr oft, Charles 1995. A Critical Dictionary of Psychoanalysis. London: Penguin Books.

S a a r m a, Jüri 1970. Kohtupsühhiaatria. Tallinn: Valgus.

Unt, Mati 1976. Igavesti surev talu. - M. Unt, Must mootorrattur. Tallinn: Eesti Raamat, lk 18-20. 
Unt, Mati 2001. Graal! - Loomingu Raamatukogu, nr 20. Tallinn: Perioodika AS. Unt, Mati 2004. Theatrum mundi. Tartu: Ilmamaa.

Un t, Mati 2006. Vend Antigone, ema Oidipus. - Loomingu Raamatukogu, nr 1-2. Tallinn: SA Kultuurileht.

Unt, Mati 2008. Kogutud teosed 2. [Tartu:] Hermes.

Unt, Mati 2009. Kogutud teosed 3. [Tartu:] Hermes.

V a hing, Vaino 1990. Võrdlusi ja meenutusi. - V. Vahing, E me ipso. Ülestähendusi 1969-1987. Tallinn: Eesti Raamat, lk 100-103.

Vahing, Vaino 2004. Noor Unt. - Loomingu Raamatukogu, nr 1-3. Tallinn: Perioodika AS.

V a hing, Vaino 2005. Seisund kui tervik. - V. Vahing, Vaimuhaiguse müüt. Tartu: Ilmamaa, lk 234-247.

Vahing, Vaino 2008. Üks hetk Mati Undiga. - Undi-jutud. Mälestusi Mati Undist. [Tartu:] Hermes, lk 299-301.

Vaimude tund 2000 = Mati Unt lavastab Kadrioru lossis „Vaimude tundi”. - Eesti Päevaleht, 7. X. (http://epl.delfi.ee/news/kultuur/mati-unt-lavastab-kadriorulossis-vaimude-tundi?id=50844197) (4. II 2016).

\section{The psychoanalytical Unt}

Keywords: Mati Unt, psychoanalysis, Greek mythology, C. G. Jung, Estonian drama

A possible approach to the oeuvre of Mati Unt (1944-2005) has to do with psychoanalysis. Mati Unt's interest in psychology and psychiatry developed during his student years at the University of Tartu, reaching its height during the theatre reform of the 1960s-1970s. A psychoanalytical substrate can be observed in both Unt's prose and drama, as well as in his stage productions. The analysis is based on C. G. Jung's theories and Unt's creative interpretation of Jung's views. Also, some light is thrown on how Unt's interest in psychoanalysis was kindled by his sensitive nature and some facts of his personal life.

Maarja Vaino (b. 1976), PhD, literary historian, Director of Anton Hansen-Tammsaare Museum, maarja.vaino@gmail.com 